\title{
Evaluation of non-radioactive trivalent DNA probe (LT, ST1a, ST1b) for detecting enterotoxigenic Escherichia coli
}

\author{
PA Chapman, CM Daly
}

\begin{abstract}
Aims: To evaluate a digoxigeninlabelled trivalent DNA probe (LT, ST1a, ST1b) for detecting enterotoxigenic Escherichia coli (ETEC), by comparison with a cell culture assay for detecting $L T$, individual DNA probes for LT, ST1a and ST1b, and an enzyme immunoassay for detecting ST1.

Methods: A 1268 base pair DNA fragment, containing parts of the genes for $E$ coli heat labile enterotoxin (LT) and heat stable enterotoxins (ST1a and ST1b), was random prime labelled with digoxigenindUTP. The labelled DNA was used as a probe in colony hybridisation reactions to examine $180 \mathrm{E}$ coli strains of which 92 had previously been shown by a cell culture assay to produce LT. Six LT negative ST1 positive $E$ coli, 34 Verotoxin producing $E$ coli (VTEC), and 84 organisms from other genera were also examined. All organisms other than VTEC were isolated from travellers returning from abroad with diarrhoea. All $E$ coli strains were retested by cell culture for LT, and were tested by enzyme immunoassay (EIA) for ST1, and by the trivalent and individual DNA probes.
\end{abstract}

Results: All 81 isolates, that on retesting by cell culture were positive for $L T$, also hybridised with the trivalent and LT probes; 27 of these were also enzyme immunoassay (EIA) positive for ST1 of which 24 hybridised with the ST1b probe and three with the ST1a probe. Of 99 isolates, that on retesting by cell culture were negative for $L T$, all were negative by LT probe and only three were EIA positive for ST1; these three were positive by both trivalent and ST1b probes. Four isolates were positive by the trivalent probe but negative by cell culture and EIA; all four were positive by ST1b probe. Compared with the cell culture assay for LT, the probe had a sensitivity and specificity both of $100 \%$; compared with the EIA for ST1, the probe had a sensitivity of $100 \%$ and specificity of $88 \%$. Conclusions: The trivalent DNA probe is a sensitive, specific, and reliable method for detecting ETEC that should be considered for use by diagnostic microbiology laboratories.

$(\mathcal{F}$ Clin Pathol 1993;46:309-312)
Diarrhoea is the most common health problem in travellers going from developed to less developed countries: about a third develop it during their travels or shortly after returning home. ${ }^{1}$ Strains of enterotoxigenic Escherichia coli (ETEC) producing a heat labile enterotoxin (LT) and/or either of two heat stable enterotoxins (ST1a, ST1b) are a major cause of diarrhoea in children and adults in less developed countries. ${ }^{2}$ LT positive ETEC are a common cause of diarrhoea in travellers returning to the United Kingdom, both from less developed countries in the tropics, and from the popular Mediterranean holiday destinations of Western Europe. ${ }^{3}$

The aim of this study was to evaluate a recently developed trivalent DNA probe ${ }^{4}$ for detecting the genes encoding LT, ST1a, and ST1b, by comparison with cell culture assay for $L T,{ }^{5}$ a commercial enzyme immunoassay (ST-EIA, Unipath) for detecting ST1, and individual DNA probes for LT, ST1a, and ST1b.

\section{Methods}

Test strains included $92 \mathrm{LT}$ positive and 88 LT negative $E$ coli isolated in previous studies $^{356}$ and during subsequent examination of faecal samples for ETEC at Sheffield Public Health Laboratory, and seven strains of $E$ coli known to produce a toxic effect resembling that of LT in one or more of three cell culture assays (Y1, Vero, and $\mathrm{CHO}$ ). To check the specificity of the probe, six LT negative ST positive $E$ coli (three producing ST1a only and three producing ST1b only) that had been isolated from travellers with diarrhoea returning to Japan and confirmed using DNA probes ${ }^{7}$ and polymerase chain reaction, ${ }^{8} 34$ Verotoxin producing $E$ coli (VTEC) of various serogroups isolated in previous studies, ${ }^{910}$ and strains of various other genera isolated from returned travellers with diarrhoea (20 shigellae, 14 salmonellae, 6 vibrios, 4 Plesiomonas shigelloides, 16 Providencia alcalifaciens and 24 Aeromonas hydrophila) were also used. All strains had been stored in nutrient broth with $15 \%$ glycerol at $-70^{\circ} \mathrm{C}$ since first isolation. All ETEC strains (except the control strains from Japan) were retested by a Y1 cell assay, a Vero cell assay, and the ST-EIA, at the same time as they were tested using the DNA probes.

For cell culture assays, Y1 cells and Vero cells were grown, maintained, and used to 
detect LT, as described before. ${ }^{56}$ Known LT positive and LT negative strains were included with each groups of tests.

A commercial competitive enzyme immunoassay for ST1 (ST-EIA, Unipath) was performed, as recommended in the supplier's instructions. As an addition to the test procedure, culture supernatant fluids from known ST1 positive and ST negative $E$ coli strains were included in each batch of tests. $\mathrm{OD}_{490}$ of tests were read on a Dynatech MR5000 microplate spectrophotometer and results calculated using a cutoff value recommended by the suppliers.

The trivalent and individual DNA probes were prepared from $E$ coli C-600 harbouring a plasmid pKAD008 containing a 1268 base pair sequence, including one fragment each of the LT and ST1b genes and two tandem copies of a fragment of the ST1a gene; this plasmid was developed and kindly supplied by Dr Akio Abe.

The $E$ coli C-600 strain was grown for 18 hours at $37^{\circ} \mathrm{C}$ in 1 litre of LB broth ${ }^{11}$ with $200 \mu \mathrm{g} / \mathrm{ml}$ ampicillin, and plasmid DNA extracted by a previously described alkaline lysis method. ${ }^{11}$ Plasmid DNA was further purified by centrifugation in a caesium chloride/ethidium bromide density gradient, followed by removal of ethidium bromide and caesium chloride and ethanol precipitation of the DNA. ${ }^{11}$ The DNA was dissolved in water and the concentration determined by standard methods. ${ }^{11}$ To obtain the 1268 base pair fragment used as a trivalent probe, about $2 \mu \mathrm{g}$ of plasmid DNA was digested with 10 units of XbaI (Pharmacia), and to obtain the 676, 236, and 173 base pair fragments used, respectively, as individual probes for LT, ST1b, and ST1a, about $2 \mu \mathrm{g}$ of plasmid DNA was digested with 10 units each of $\mathrm{XbaI}$ and EcoRI. Fragments were separated in a $1 \%$ agarose gel, the DNA purified from the gel by electroelution, ${ }^{11}$ and random prime labelled with digoxigenin-dUTP according to the instructions supplied with a commercial kit (DNA Labelling and Detection Kit Nonradiactive, Boehringer-Mannheim).

Organisms to be tested with the probe were grown overnight at $37^{\circ} \mathrm{C}$ in brain-heart infusion broth (Oxoid) and inoculated, using a multipoint device, on to nylon hybridisation membrane (Hybond-N, Amersham) on the surface of brain heart infusion agar. Plates were then incubated at $37^{\circ} \mathrm{C}$ for 6 hours, the membranes removed, and colonies lysed by a

Table 1 Further results on 18 strains of $E$ coli

\begin{tabular}{|c|c|c|c|c|c|c|c|}
\hline $\begin{array}{l}\text { Y1 cell } \\
\text { assay }\end{array}$ & $\begin{array}{l}\text { Vero cell } \\
\text { assay }\end{array}$ & $\begin{array}{l}\text { Heat } \\
\text { labile }\end{array}$ & $\begin{array}{l}\text { Neutralised } \\
\text { by anti-CT }\end{array}$ & $\begin{array}{l}\text { Cytotoxic } \\
\text { effect }\end{array}$ & $\begin{array}{l}\text { Trivalent } \\
\text { probe }\end{array}$ & LT Probe & $\begin{array}{l}\text { Number of } \\
\text { strains }\end{array}$ \\
\hline \multicolumn{8}{|c|}{ Test strains showing LT-like effect on cell cultures $(n=7)$} \\
\hline+ & + & - & - & + & - & - & 2 \\
\hline+ & - & + & - & - & - & - & 3 \\
\hline+ & + & - & \pm & + & - & - & 1 \\
\hline \multirow{2}{*}{\multicolumn{8}{|c|}{ Control LT positive strains $(n=2)$}} \\
\hline & & & & & & & \\
\hline+ & + & + & + & - & + & + & 2 \\
\hline
\end{tabular}

Y1 and Vero cell assays, $+=$ cytopathic effect similar to that of LT; heat labile, $+=$ cytopathic effect destroyed by heating culture supernatant fluids to $65^{\circ} \mathrm{C}$ for 30 minutes; neutralised by anti-CT, $+=$ toxic effect neutralised by prior incubation of culture supernatant fluids with ly cytotoxic over a period of 72 hours. standard method. ${ }^{11}$ Membranes were air dried for about 30 minutes, and the DNA coupled to the membrane by wrapping in clingfilm and exposing to ultraviolet light from a transilluminator, for 3 minutes on each side.

Membranes were prehybridised by immersion in hybridisation solution (5 $\mathrm{x}$ SSC, ${ }^{11}$ $50 \%$ deionised formamide, $0 \cdot 1 \% \mathrm{~N}$-lauroylsarcosine, $0.02 \%$ sodium dodecyl sulphate, and $0.5 \%$ blocking reagent (supplied with the DNA detection kit)) and overnight incubation at $42^{\circ} \mathrm{C}$ with gentle agitation. The previously labelled DNA was denatured by heating to $95^{\circ} \mathrm{C}$ for 15 minutes, followed immediately by rapid cooling in an ice bath, and added to fresh hybridisation solution; this was used to replace the solution on the membrane for a further overnight incubation at $42^{\circ} \mathrm{C}$. Prehybridisation was performed each time with fresh solution, whereas the solution containing labelled DNA was subsequently stored at $-20^{\circ} \mathrm{C}$ for repeated use up to a maximum of 20 times. The membranes were washed twice for 5 minutes each with $2 \times$ SSC, $0 \cdot 1 \%$ SDS at ambient temperature, and twice for 15 minutes each time with $0.1 \times$ SSC, $0.1 \%$ SDS at $42^{\circ} \mathrm{C}$. Bound digoxigenin labelled probe was then detected using a monoclonal antibody to digoxigenin conjugated to alkaline phosphatase and a chromogenic substrate, following a protocol supplied with the DNA detection kit.

$E$ coli C-600 containing plasmid pKAD008, a plasmid-free $E$ coli C-600, and wild strains of $E$ coli, known to be LT positive ST1 positive, LT positive ST1 negative, LT negative ST1 positive, and LT negative ST1 negative, were used as control strains on each membrane.

\section{Results}

Eleven organisms previously confirmed to be LT positive by cell culture and a coagglutination assay ${ }^{12}$ were negative by cell culture on repeat testing; none hybridised with the trivalent or LT probes. Seven strains previously showing a toxic effect on cell culture(s) similar to that of LT, on retesting, produced a toxic effect on Y1 or Vero cells that, unlike LT, was either heat stable, non-neutralisable with anti-cholera toxin, or was progressively cytotoxic; again, none hybridised with the trivalent or LT probes (table 1). A comparison of the final results obtained with all methods is presented in table 2. All 81 isolates, that on retesting by cell culture were positive for LT, also hybridised with the trivalent and LT probes; 27 of these 81 were also EIA positive for ST1 of which 24 hybridised with the Stlb probe and three with the ST1a probe. Of 99 isolates, that on retesting by cell culture were negative for $L T$, all were negative by LT probe and only three were EIA positive for ST1; these three were positive by both trivalent and ST1b probes. Four isolates were positive by the trivalent probe but negative by cell culture and EIA; all four were positive by ST1b probe. The six strains from 
Table 2 Summary of comparison of cell culture, ST-EIA, trivalent DNA probesand individual DNA probes for detecting $E$ coli producing LT or ST1, or both

\begin{tabular}{llllll}
\hline $\begin{array}{l}\text { Cell culture and } \\
\text { ST-EIA results }\end{array}$ & $\begin{array}{l}\text { Trivalent } \\
\text { probe } \\
\text { positive }\end{array}$ & $\begin{array}{l}\text { Trivalent } \\
\text { probe } \\
\text { negative }\end{array}$ & $\begin{array}{l}\text { LT probe } \\
\text { positive }\end{array}$ & $\begin{array}{l}\text { ST1a probe } \\
\text { positive }\end{array}$ & $\begin{array}{l}\text { ST1b probe } \\
\text { positive }\end{array}$ \\
\hline $\begin{array}{l}\text { Cell culture positive/ } \\
\text { EIA positive }(\mathrm{n}=27)\end{array}$ & 27 & 0 & 27 & 3 & 24 \\
$\begin{array}{l}\text { Cell culture positive/ } \\
\text { EIA negative }(\mathrm{n}=54)\end{array}$ & 54 & 0 & 54 & 0 & 0 \\
$\begin{array}{l}\text { Cell culture negative/ } \\
\text { EIA positive }(\mathrm{n}=3)\end{array}$ & 3 & 0 & 0 & 0 & 3 \\
$\begin{array}{l}\text { Cell culture negative/ } / \\
\text { EIA negative }(\mathrm{n}=96)\end{array}$ & 4 & 92 & 0 & 0 & 4 \\
\hline
\end{tabular}

Japanese travellers all hybridised with the trivalent probe and with the correct monovalent probes. Compared with the cell culture assay for LT the probe had a sensitivity and specificity of $100 \%$; compared with the EIA for ST1 the probe had a sensitivity of $100 \%$ and specificity of $88 \%$. None of the VTEC and strains of various other genera hybridised with the trivalent probe.

\section{Discussion}

Despite the importance of ETEC as a cause of diarrhoea in returning travellers, ${ }^{23}$ few diagnostic microbiology laboratories recognise them. This may in part be due to the difficulties in previously recommended methods, particularly those for detecting ST producers. ${ }^{13}$

Cell culture assays for LT can be simple, economical, and sensitive, and are widely recommended for diagnostic use. ${ }^{14}$ Such assays, however, need to be performed in laboratories with specialist cell culture facilities. While the $\mathrm{Y} 1$ cell assay is a reliable and sensitive test for LT, other cell culture assays, such as that using $\mathrm{CHO}$ cells ${ }^{15}$ may be affected by the cytolethal distending toxin of $E$ coli, and if not investigated further this effect may be confused with that of LT. ${ }^{16}$ Previous reports ${ }^{56}$ and the present study have highlighted the need for precise confirmation that toxic effects displayed by cell culture are due to LT. LT is antigenic and various immunoassays have been described for its detection; commercial kits for detecting $\mathrm{LT}$ have been evaluated, but lack the sensitivity of cell culture. ${ }^{12}$ In the present study, 11 isolates previously confirmed as positive for LT by cell culture and a coagglutination assay ${ }^{12}$ were found to be negative for LT when retested by cell culture and when examined by the probes. Such discrepancies, due to deletion of fragments of DNA from toxin genes or loss during storage and subculture, of entire plasmids carrying these genes, have been reported by others ${ }^{17}{ }^{18}$; such deletions could have occurred in the strains used for this study as they had been stored for varying lengths of time and subcultured several times since first isolation. The EIA used in the present study has been evaluated before, and has given good results, ${ }^{19}$ the assay is, however, time consuming to perform and expensive.

The use of a trivalent probe to detect ETEC producing LT, St 1a, or ST1b offers a sensitive and reliable means of detecting
ETEC. Compared with cell culture the probe had a sensitivity and specificity of $100 \%$ for detecting LT; compared with the EIA the sensitivity and specificity for detecting ST1 were $100 \%$ and $88 \%$ respectively. Although a slightly subjective assessment, LT positive strains gave a strong positive colour reaction using the probe; those producing ST only gave a weaker reaction; $\mathrm{Dr}$ Abe and colleagues, who constructed the 1268 base pair sequence, ${ }^{4}$ used as a probe in this study, also noted a weak signal in strains producing ST only. However, using the trivalent probe, they correctly identified strains producing ST1a only, which did not react with a biotinylated monovalent ST1a probe used in previous studies. ${ }^{70}$ In this study, we found four strains of $E$ coli that were LT negative by cell culture, and which gave a weak reaction with the trivalent probe, characteristic of strains producing ST only; these four strains were negative on repeated testing by EIA for ST1, but did hybridise with the probe for ST1b. Scotland and colleagues ${ }^{19}$ found strains that harboured the ST1 gene, but presumably failed to express this, giving negative results for ST in bioassays, and although this could account for our findings, it is possible also that the trivalent probe offers greater sensitivity than the EIA for detecting ST1 positive strains.

Various other organisms have been associated with diarrhoea in travellers returning from abroad, ${ }^{31-23}$ some of which have been reported, usually based on results of cell culture assays, to produce LT-like toxins. No such strains examined in this study hybridised with the trivalent probe.

We conclude that the trivalent DNA probe is a sensitive, specific, and reliable method for detecting ETEC. It should be considered for use by diagnostic microbiology laboratories wishing to examine returning travellers for the presence of these organisms.

We thank Dr Akio Abe of the Kitasato Institute, Tokyo japan, for supplying the $E$ coli $\mathrm{C}-600$ strain harbouring plasmid pKAD008 and the six strains isolated from Japanese travellers, Unipath Ltd for supplying the ST-EIA kit, and colleagues at Sheffield PHL for their help with this study.

1 Anonymous. Consensus conference on travelers' diarrhea held by the National Institutes for Health, USA. $\mathcal{F} A M A$ 1985;253:2700-4.

2 Guerrant RL. Microbial toxins and diarrhoeal disease: introduction and overview. In: Evered D, Whelan J, eds. Microbial Toxins and diarrhoeal disease. Ciba Foundation Symposium No 112. London; Pitman Medical 1985: $1-27$.

3 Chapman PA, Mitchelmore DL. A two year survey of the incidence of heat-labible enterotoxin-producing returning to the Sheffield area. Epidemiol Infect 1988;101:239-47.

4 Abe A, Komase K, Bangtrakulnonth A, Ratchtrachenchat OA, Kawahara K, Danbara H. Trivalent heat-labile and heat-stable enterotoxin probe conjugated with
horserdish peroxidase for the detection of enterotoxihorserdish peroxidase for the detection of enterotoxi-
genic Escherichia coli by hybridisation. $\mathcal{f}$ Clin Microbiol genic Escherichia
1990;28:2616-20

5 Chapman PA, Swift DL. A simplified method for detecting the heat-labile enterotoxin of Escherichia coli. $\mathcal{f ~ M e d}$ Microbiol 1984;18:399-403.

6 Chapman PA. Detection of heat-labile enterotoxin-producing Escherichia coli and their prevalence in acute diarrhoea. [Thesis]. University of Sheffield 1987:98-104.

7 Kirii Y, Danbara H, Komase K, Arita H, Yoshiwaka M. Detection of enterotoxigenic Escherichia coli by colony hybridisation with biotinylated enterotoxin probes. $\mathcal{F}$ Clin Microbiol 1987;25:1962-5. 
8 Abe A, Obata $\mathrm{H}$, Matshushita $\mathrm{S}$ et al. A sensitive method for the detection of enterotoxigenic Escherichia coli by the polymerase chain reaction using multiple primer pairs. Zbl Bakt 1992;277:170-8.

9 Chapman PA, Wright D, Norman P. Verotoxin-producing Escherichia coli infections in Sheffield: cattle as a possible source. Epidemiol Infect 1989;102:439-45.

10 Chapman PA, Jewes L, Siddons CA, Norman P, George SL. Verocytotoxin-producing Escherichia coli infections in Sheffield: 1985-1989. PHLS Microbiology Digest in Sheffield:

11 Sambrook J, Fritsch EF, Maniatis T. Molecular cloning. 2nd edn. New York: Cold Spring Harbour Press, 1989.

2 Chapman PA, Daly CM. Comparison of Y1 mouse adrenal cell and coagglutination assays for detection of Escherichia coli heat-labile enterotoxin. 7 Clin Pathol 1989;42:755-8 13 Gross RJ. Escherichia coli diarrhoea. $\mathcal{F}$ Infect

14 Pedler SJ, Orr KE. Examination of faeces for bacterial pathogens (ACP Broadsheet 124). 7 Clin Pathol 1990;43:410-15.

15 Guerrant RL, Brunton LL, Schnaitman TC, Rebhun LI, Gilman AG. Cyclic adenosine monophosphate and alteration of chinese hamster ovary cell morphology: a rapid, sensitive in-vitro assay for the enterotoxins of Vibrio cholerae and Escherichia coli. Infect Immun 1974;10:320-7.

16 Johnson WM, Lior $\mathrm{H}$. Response of chinese hamster ovary
Escherichia coli and possible misinterpretation as heatlabile enterotoxin. FEMS Microbiol Letts 1987;43:19--23.

17 Echeveria P, Seriwatana PJ, Taylor DN, et al. Plasmids coding for colonisation factor antigens I and II, heatlabile enterotoxin, and heat-stable enterotoxin A2 in Escherichia coli. Infect Immun 1986;51:626-30.

18 Sommerfelt H, Svennerholm AM, Kalland KH, Haukanes BI, Bjorvatn B. Comparative study of colony hybridisation with synthetic oligonucleotide probes and enzymetion with synthetic oligonucleotide probes and enzyme-
linked immunosorbent assay for identification of linked immunosorbent assay for identification of enterotoxigenic

19 Scotland SM, Willshaw GA, Said B, Smith HR, Rowe B. Identification of Escherichia coli that produce heat-stable enterotoxin $\mathrm{ST}_{\mathrm{A}}$ by a commercially available enzyme-linked immunoassay and comparison of the assay with infant mouse and DNA probe tests. 7 Clin Microbiol 1989;27:1697-9.

20 Danbara H. Identification of enterotoxigenic Escherichia coli by colony hybridisation using biotinylated LT1h, ST $1 \mathrm{a}$ and Stlb enterotoxinprobes. In: Macario AJL, Macario EC, eds. Gene probes for bacteria. San Diego: Academic Press, 1990:167-78.

21 Gracey M, Burke V, Robinson J, Masters PL, Stewart J, Pearman J. Aeromonas spp in travellers' diarrhoea. $\mathrm{Br}$ Med $\mathcal{f} 1984 ; 289: 658$

22 Haynes J, Hawkey PM. Providencia alcalifaciens and travellers' diarrhoea. Br Med F 1989;299:94-95.

23 Chapman PA. Vibrio alginolyticus and diarrhoeal disease. f Diarrhoeal Dis Res 1987;5:40. 